\title{
Determination of Modal Parameters of Historical Masonry Minarets by using Operational Modal Analysis
}

\author{
Kemal Hacıefendioğlu, Gökhan Demir, Emre Alpaslan \\ Ondokuz Mayis University \\ Ondokuz Mayıs University, Department of Civil Engineering, Samsun, Turkey \\ hckemal@ omu.edu.tr; gokhan.demir@ omu.edu.tr; emre.alpaslan@omu.edu.tr
}

\begin{abstract}
This study conducted to investigation of modal parameters (such as mode shapes, modal frequencies) of a masonry type historical minaret by performing numerical and experimental analys es. Operational Modal Analysis (OMA) Technique is used for experimental study to obtain modal parameters of historical masonry minarets. For this purpose, Büyük Mosque located in Samsun, Turkey, was chosen for the experimental analysis. The Frequency Domain Decomposition (FDD) method is utilized to identify the natural frequencies and mode shapes experimentally. ANSYS software is used to carry out 3D finite element modelling of the historical masonry minaret and determine the natural frequencies and mode shapes of the minaret analytically. Furthermore, the finite element model of the minaret is calibrated according to the experimental results by using the Response Surface based finite element (FE) model calibration technique to obtain more accurate results of the modal parameters of the structure. The results of experimental, initial and calibrated finite element model were compared to each other. It can be noticed significant differences when comparing the results of the experimental and analytical with the initial conditions. Model calibration techniques are necessary to obtain more reasonable finite element model.
\end{abstract}

Keywords: Historical Masonry Minaret, Frequency Domain Decomposition, Operational Modal Analysis, Finite Element Model Calibration

\section{Introduction}

Historical structures in Turkey have a large role for the historical touch's view and historically common presentation of the country. Because of increasing the importance of historical masonry structures, in the last decades, conservation and structural safety assessment of these kind of structures are particularly critical. Minarets, one type of the historic structures, are to provide a vantage point from which the muezzin can call people to prayer. The basic form of minarets consists of three parts which are a base, shaft, and a gallery. Minarets may build as conical (tapering), square, cylindrical, or polygonal (faceted).

With a result of collapses of the some minarets such as Bodurga minaret in Çankırı [1], Centre minaret in Bingöl [2], Kadıköy minaret in Sultandağı [3] and general collapses of the minarets [4] in Turkey, the researchers have focused on the determination methods including both experimental and analytical investigations to examine dynamic characteristics of these type of structures. Evaluating the dynamic characteristics (modal parameters; mode shapes, modal frequencies and damping ratios) of a structure is carrying out with experimental modal analysis (EMA) and operational modal analysis (OMA) techniques. In the experimental modal analysis, the specific input force (impulse hammer, drop weight and electrodynamics shaker) is applied to the structure to obtain its modal parameters. Operational modal analysis uses the unknown excitations such as wind, traffic, wave, etc. loads. This study performs the Operational Modal Analysis technique to determine the dynamic characteristics of the historical masonry minaret.

Most of the previous studies investigated to determine the modal parameters of historical masonry structures [5-9]. Because only few studies [10-11] were conducted about the determining the modal parameters of historical masonry minarets, in this study, it is intended to perform experimentally and numerically analyses to investigate the modal parameters of a masonry type historical minaret. For this purpose, ANSYS [12] software program is used to carry out the finite element modelling of historical masonry minaret. 


\section{Formulation}

In general, Frequency Domain Decomposition (FDD) method is used for Operational Modal Analysis in the civil engineering industries. In the FDD technique, the spectral density matrix is approximately separated into a set of single degree of freedom (SDOF) systems utilizing the Singular Value Decomposition. It is possible to get exact results in the case where loading is white noise, the structure is lightly damped, and if the mode shapes of close modes are geometrically orthogonal. Even if these assumptions are not satisfied, the results are significantly reasonable [13]. The relationship between the input $x(t)$, and the output $y(t)$ can be written in the following form;

$$
G_{y y}(\omega)=H(\omega) \cdot G_{x x}(\omega) \cdot H^{T}(\omega)
$$

where $G_{y y}(\omega), G_{x x}(\omega)$ and $H(\omega)$ are the spectra of the measured response, unknown excitation and Frequency Response Function, respectively and superscript $\mathrm{T}$ donates transpose.

\section{Application}

A masonry historical mosque called Büyük Mosque, located in Samsun city centre on the Saathane Square, Turkey, is the selected structure for application. It is also called Valide Mosque. The Büyük Mosque which has been built on September 9, 1884, by Hac1 Ali of Batumi and repaired by Sultan Abdulaziz's mother, has a large yard and dual, hewn stone minarets with single balconies. The mosque, built of face stone, has two minarets. The big central dome is constructed with cupolas around. The star shaped windows on the walls are colored with stained glass. On the inner side of the dome, there are coloured hand drawn ornaments. The wooden minbar of the mosque is also ornamental. The mihrab is high and built of light pink marble.

Fig. 1(a) and Fig.1 (b) show the picture and the details of the minaret's approximate geometrical properties and of the mosque. The minaret is $32.07 \mathrm{~m}$ high with 99 stairs $(0.25-\mathrm{m}$ step height) from the floor to the balcony. From inside, a cylindrical shaft of constant inner diameter extends from the bottom square base up to the level of the balcony. A helical staircase, constructed from stones interlocked with the stones of the inner cylindrical shaft, rest at its centre on a common stone column at the centre of the minaret. The minaret has a $3.13 \times 3.13 \mathrm{~m}$ square base [14].

\subsection{Operational Modal Test Analysis}

The modal tests were carried out to determine the modal parameters of masonry minaret by using the OMA method. The signals due to the environmental loads (vehicle, wind, ground motions and other vibrations) were taken by using three axial wireless accelerometers and data acquisition system (Fig. 2(b)) being put into place in the same direction and different height locations 1,2 3, 4 of the minaret. The signals from accelerometers were obtained by using data acquisition network access software Testlab_V2. Measurement duration was chosen as 20 minutes and the frequency range was taken as $0-50 \mathrm{~Hz}$. The signals were gathered in $\mathrm{X}, \mathrm{Y}, \mathrm{Z}$ direction from 4 different directions in total. Fig. 1(a) illustrates the accelerometers' places on the minaret. The data gathered from the accelerometers corresponding to specified points are shown in Fig.3. The experimental modal parameters of the historical masonry minaret were obtained by ARTeMIS 1.5 software [15]. The natural frequencies and mode shapes of the minaret are acquired by using FDD technique. The signal time series for all channels and the singular values of spectral density matrices of data set obtained from the FDD technique are shown in Fig.3 and Fig.4, respectively. Moreover, experimentally obtained natural frequencies and mode shapes of first seven modes of the minaret are illustrated in Fig. 5. 


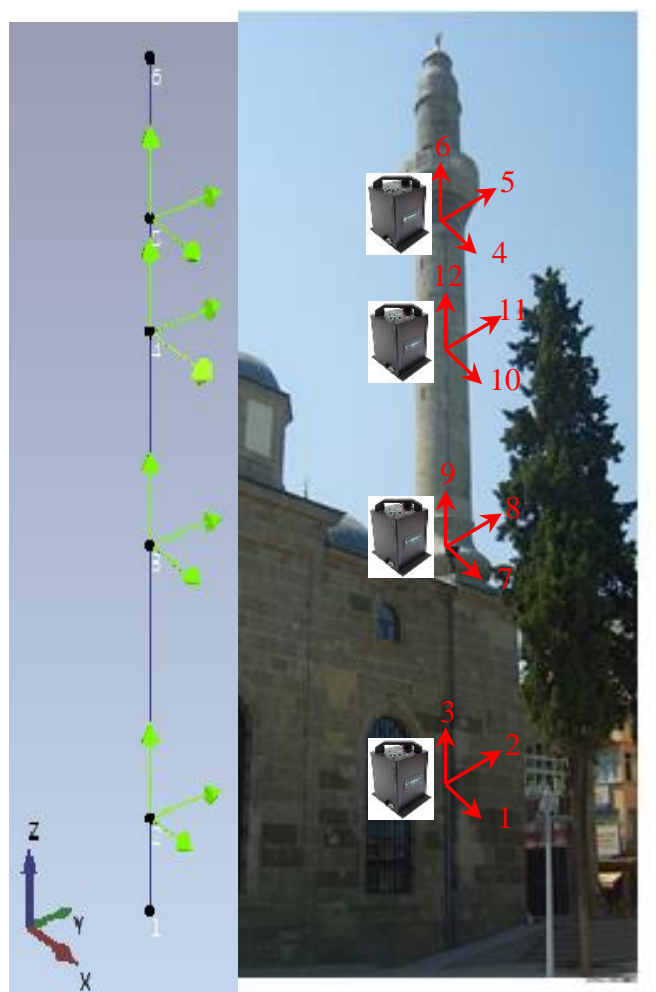

(a)

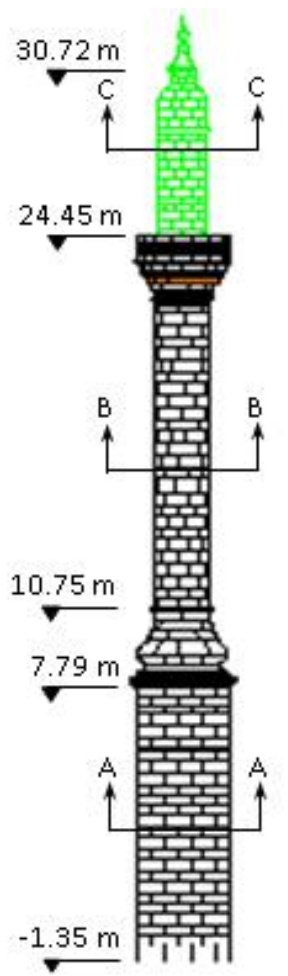

(b)
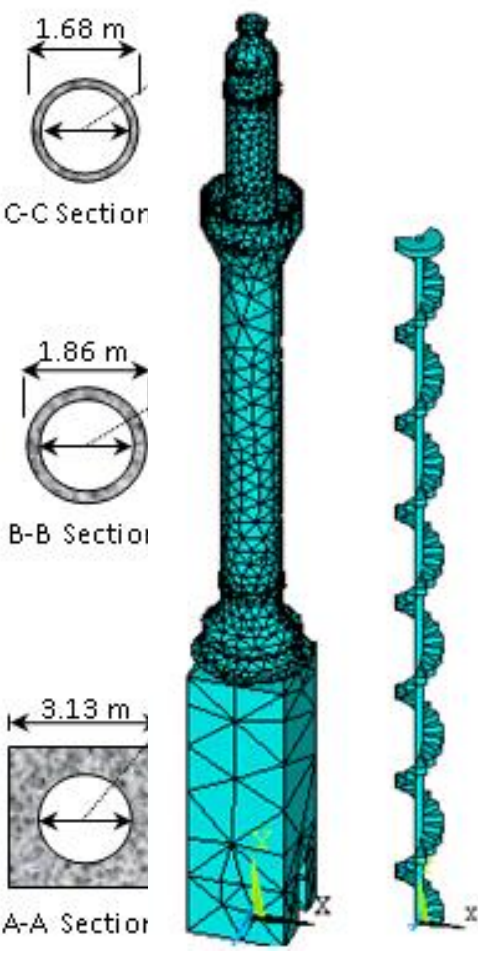

(c)

Fig. 1: (a) Total measurement setup and photograph, (b) geometrical properties and (c) finite element model of the Büyük Mosque's minaret

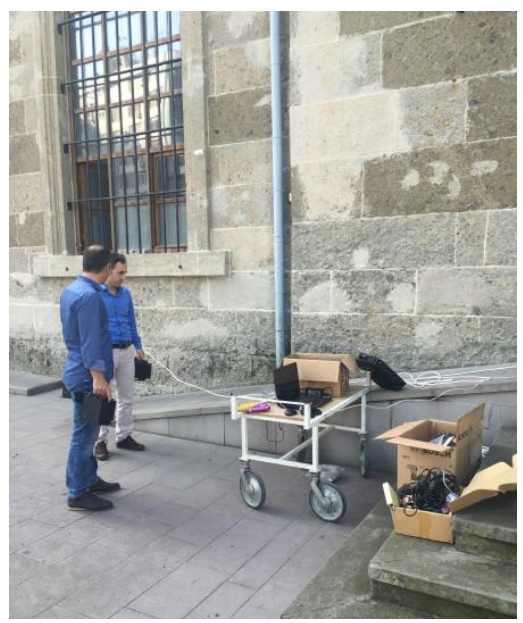

(a)

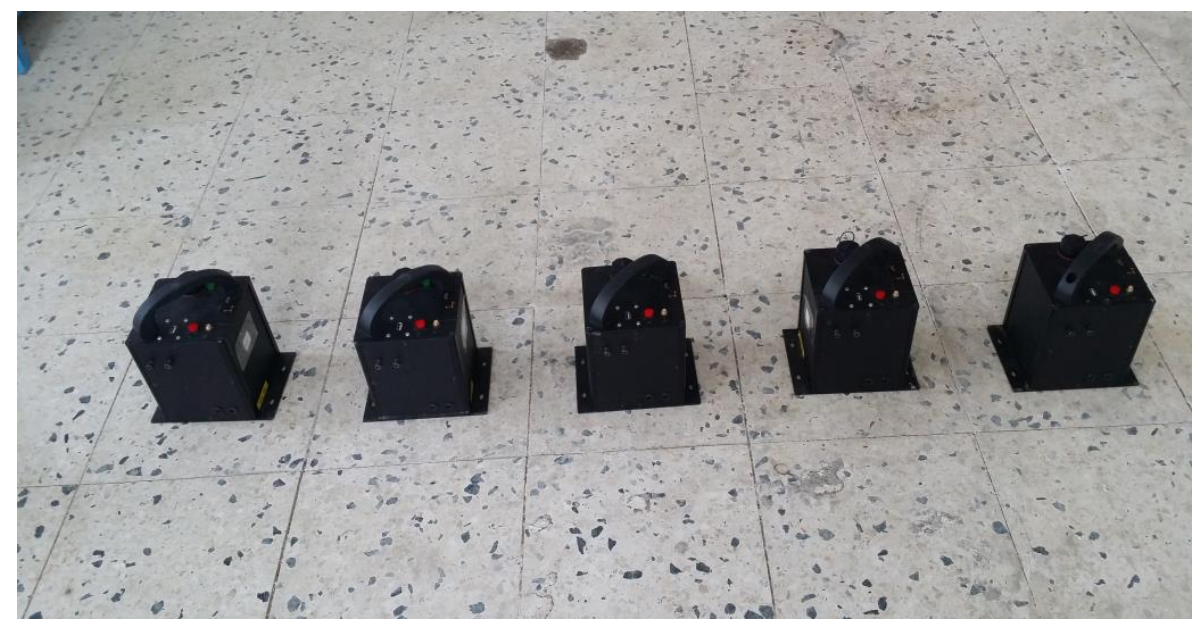

(b)

Fig. 2: (a) A view of the modal testing measurement (b) the wireless accelerometers and data acquisition system 

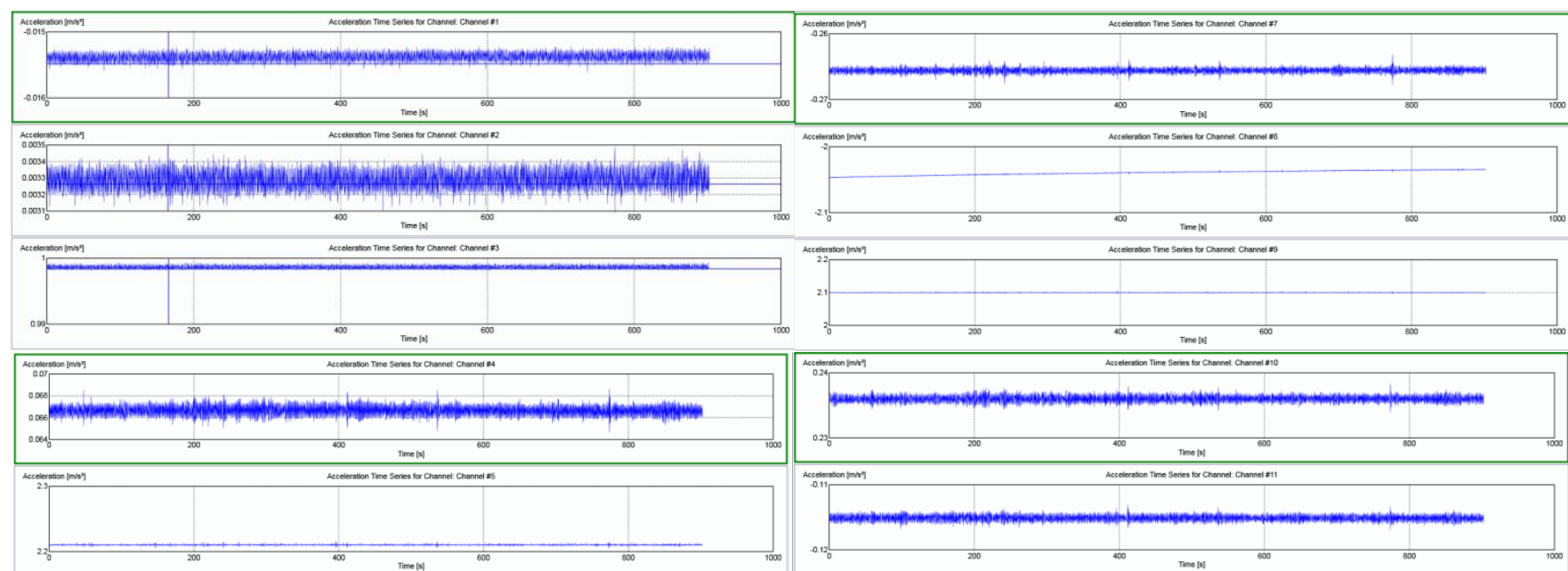

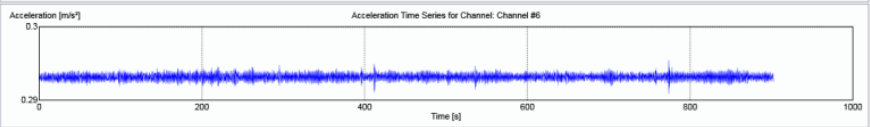

(a)

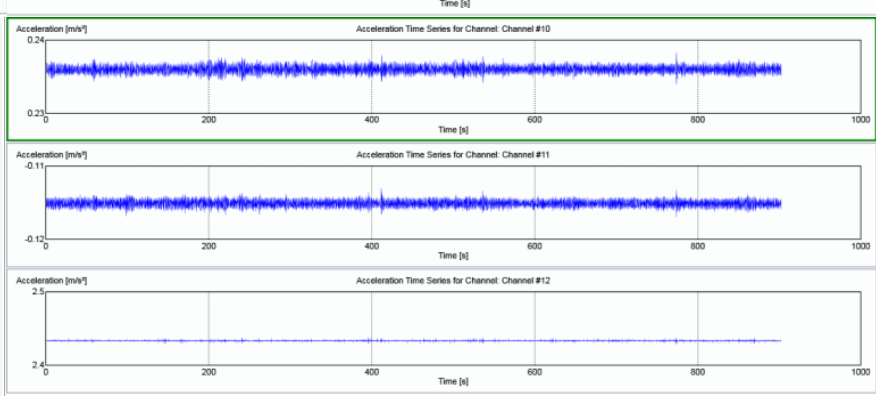

(b)

Fig. 3: Signal time series for channels (a) 1,2,3,4,5,6 (b) 7,8,9,10,11,12, respectively.

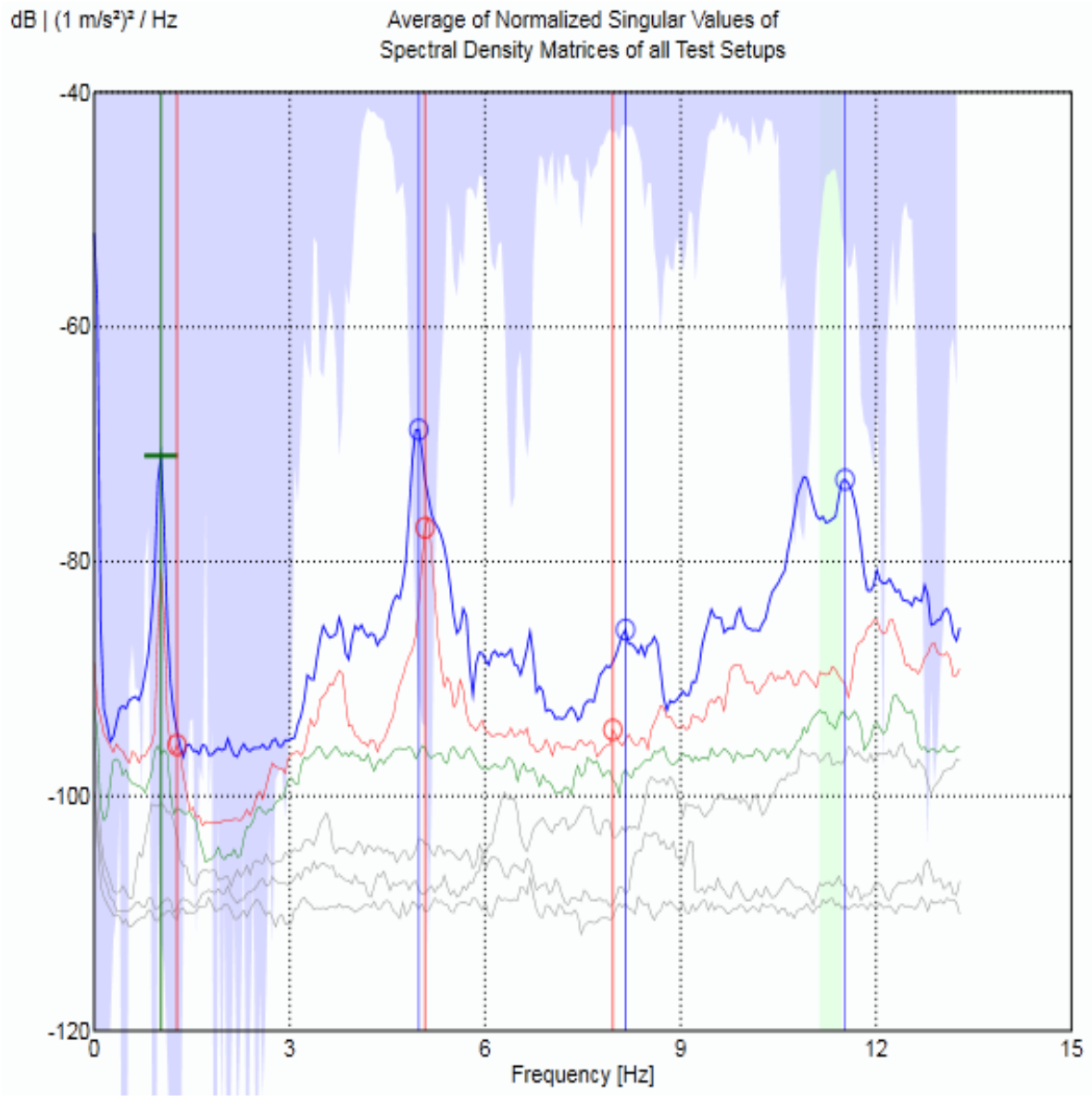

Fig. 4: Average of normalized singular values of spectral density matrices of all test setups 


\subsection{Finite Element Modelling}

In order to obtain the dynamic characteristics (frequencies, mode shapes and damping ratios) of the historical masonry minaret, a three dimensional finite element model of the Büyük Mosque was created by using ANSYS software as shown in Fig.1(c). SOLID186 elements for the three-dimensional modelling of solid structures were used to model the historical masonry minaret. This element is defined by 20 nodes; each node has 3 translational degrees of freedom, namely, $\mathrm{u}_{\mathrm{x}}, \mathrm{u}_{\mathrm{y}}$ and $\mathrm{u}_{\mathrm{z}}$. It has plasticity, creep, swelling, stress stiffening, large deflection, and large strain capabilities (ANSYS 2012). The 3D finite element model of the minaret and the stone block with stairs are shown in Fig. 1(c). The initial mechanical parameters, the modulus of elasticity, Poisson's ratio and mass density of masonry material were taken as 2000 $\mathrm{MPa}, 0.2$ and $16 \mathrm{kN} / \mathrm{m}^{3}$, respectively. In the model, linear elastic material behaviour is assumed and the stiffness degradation is neglected. It is assumed that the minaret foundation was built on rock soil media. So, initial boundary conditions, all of the degrees of freedoms under the foundation section of the minaret were accepted as fixed support.

\subsection{Finite Element Model Calibration}

The modal shapes of the masonry minaret were computed from the finite-element analysis according to the initial mechanical parameters and boundary conditions defined above (Section 3.2). The results obtained from the initial conditions are illustrated in Table 1. As shown in Table 1, there are significant differences between the frequencies obtained from the analytical and experimental analyses with the initial conditions. These mismatches may due to uncertainties mechanical properties of materials, inaccurate boundary conditions and assumptions of structural geometry. The material strength reduction in time-dependent and damages in portions of the minaret can also cause these discrepancies. So, the finite element model requires the calibration by changing the material properties and boundary conditions to approach more accurate results.

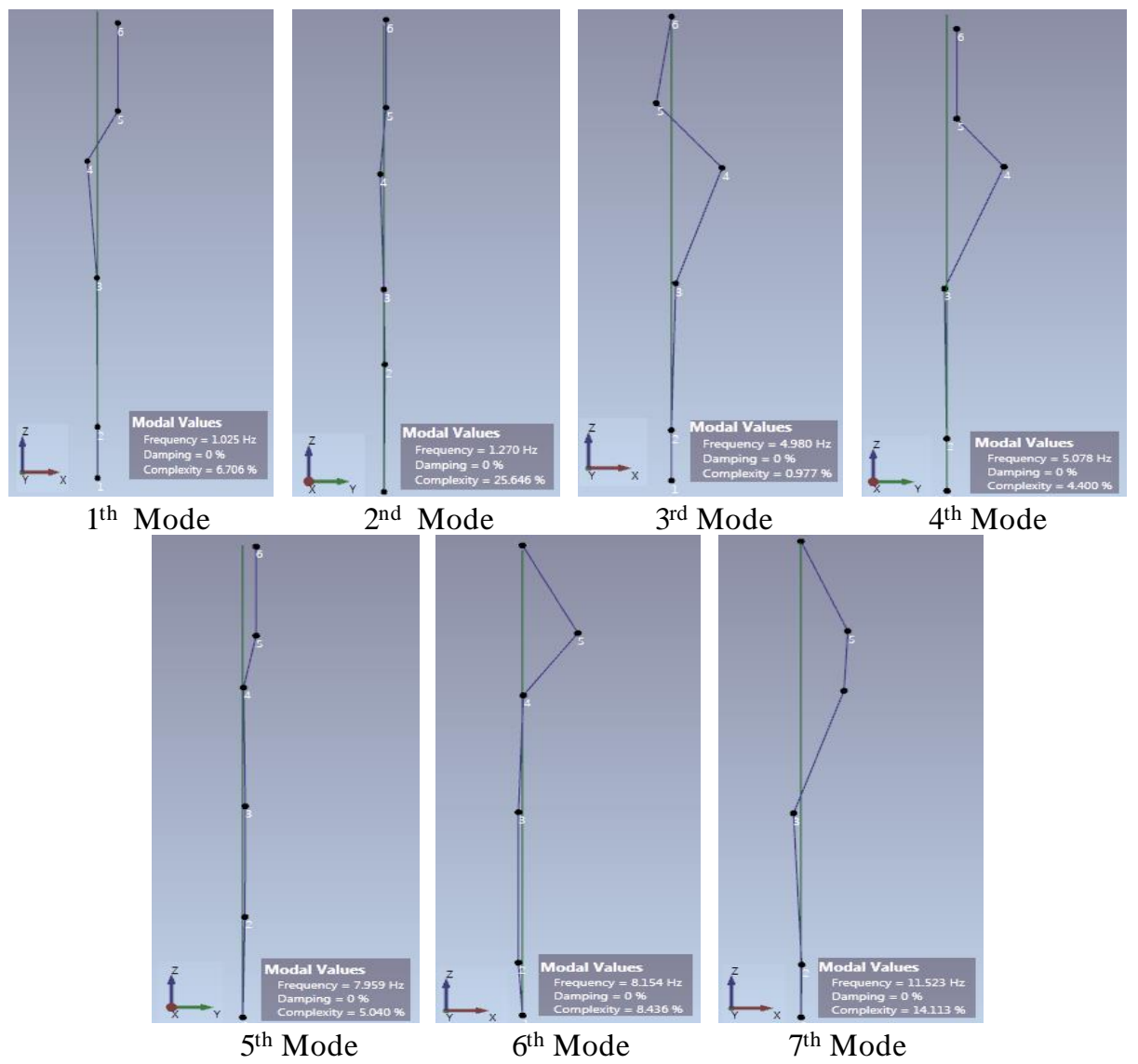

Fig. 5: Experimentally identified first seven mode shapes of the minaret 
Table 1: Analytical and experimental modal parameters

\begin{tabular}{|c|c|c|c|}
\hline & \multicolumn{2}{|c|}{ Analytical (ANSYS) } & Experimental (FDD Technique) \\
\hline $\begin{array}{c}\text { Mode } \\
\text { number }\end{array}$ & $\begin{array}{c}\text { Before calibration } \\
\text { frequencies (Hz) }\end{array}$ & $\begin{array}{c}\text { After calibration } \\
\text { frequencies (Hz) }\end{array}$ & Frequencies (Hz) \\
\hline 1 & 0.663 & 1.164 & 1.025 \\
\hline 2 & 0.668 & 1.173 & 1.270 \\
\hline 3 & 2.741 & 4.815 & 4.980 \\
\hline 4 & 2.876 & 5.051 & 5.078 \\
\hline 5 & 4.407 & 7.741 & 7.959 \\
\hline 6 & 4.685 & 8.230 & 8.154 \\
\hline 7 & 6.311 & 11.086 & 11.523 \\
\hline
\end{tabular}

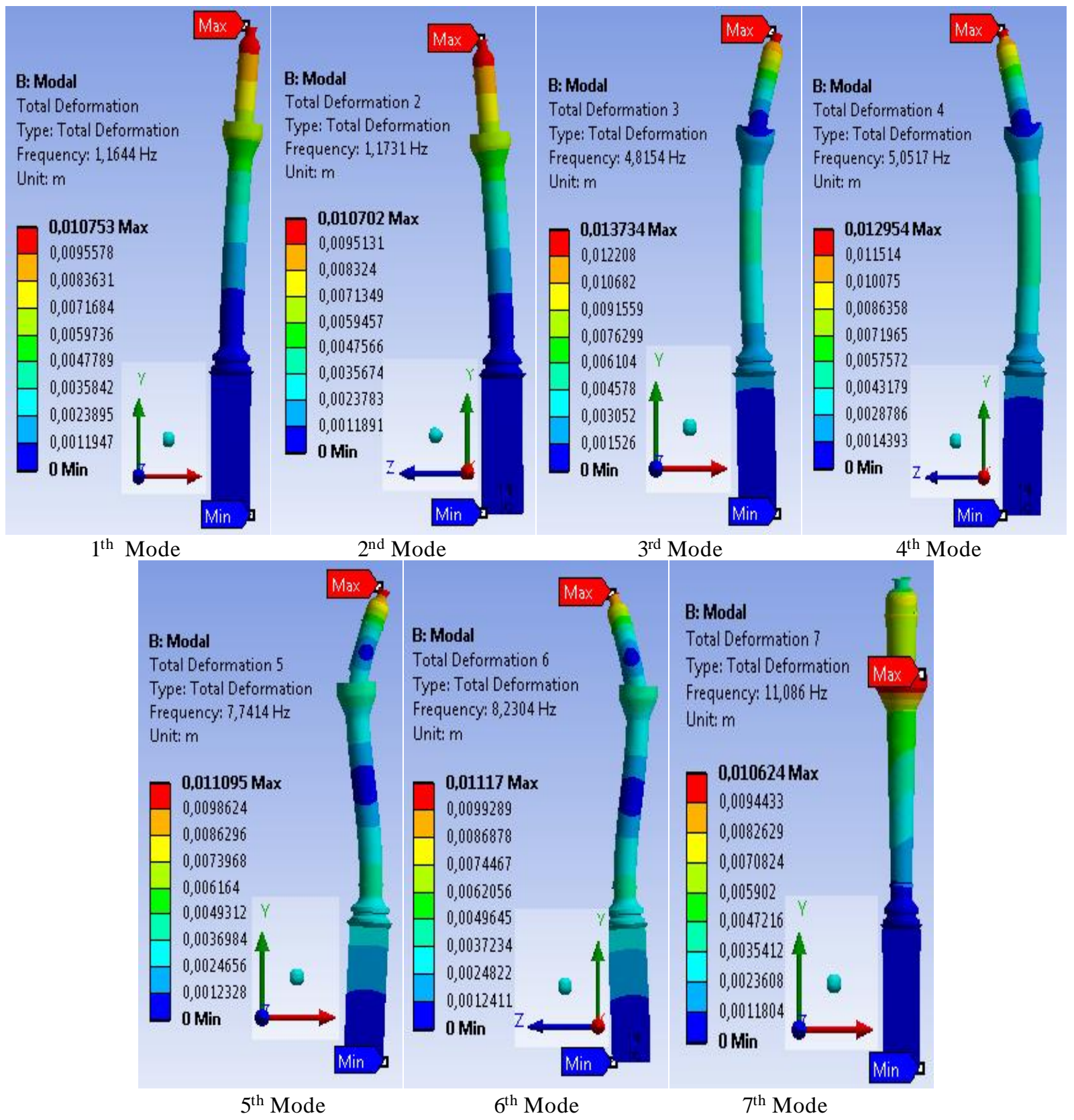

Fig. 6: Analytically identified first seven mode shapes of the minaret 
The manual or automatic model calibration methods are classically utilized in many studies. In this study, the response surface based finite element (FE) model calibration for Operational Modal Analysis was applied to the historical masonry minaret. Natural frequencies evaluated from Eigen analysis of FE model are compared with the experimental analysis and the optimal results are found by using the optimization method [16]. The aim of this method is to close the numerical results to the experimental one. The frequencies computed from the analytical analyses which are for before and after calibration and experimental modal parameters are presented in Table 1. It can be seen that the natural frequencies obtained from the finite element method show a good compatibility with those found from FDD technique after model calibration. The analytically identified first seven mode shapes of the minaret are also depicted in Fig. 6.

\section{Conclusion}

This study deals with determination of modal parameters of historical masonry minarets by using the Operational modal analysis. For this purpose, Büyük Mosque located in Samsun was chosen for the experimental analysis, finiteelement modelling and finite-element model calibration. The Operational Modal Analysis test is carried out under environmental vibrations such as traffic movements, human walking and wind loads, etc. The Frequency Domain Decomposition (FDD) method is implemented to identify the natural frequencies experimentally. ANSYS software is used to construct the minaret and determine the natural frequencies of the 3D finite element model analytically.

It can be noticed significant differences when comparing the results of the experimental and analytical with the initial conditions. Therefore, finite-element model requires to be calibrated to close the frequencies obtained from the analytical analysis to those of experimental analysis. The response surface based finite element (FE) model calibration for Operational Modal Analysis is thought to change automatically the uncertain parameters of the minaret to minimize the differences between experimentally and analytically determined modal parameters of the historical masonry minaret. Following are conclusions from this study:

- It can be concluded from the analytical results that the first seven natural frequencies are in the range between $1 \mathrm{~Hz}$ and $15 \mathrm{~Hz}$. These first seven mode shapes can be grouped into bending in $\mathrm{x}$ and $\mathrm{z}$ direction and torsional modes.

- The analytical frequencies according to the initial conditions are lower than the experimental frequencies.

- The response surface method for calibration of the finite element model is seen as a good approach. After the finite element model calibration, the differences between experimental and analytical natural frequencies decrease significantly.

\section{Acknowledgements}

The authors thank to The Prime Ministry, General Directorate of Foundations, Samsun Regional Directorate due to their support for experimental part of the study.

\section{References}

[1] B. Taşkın, P. Özdemir, and N. M. Özel, "Evaluation of Orta-Çankiri June 06, 2000 Earthquake [in Turkish]," in Proceddings of the Fifth National Conference on Earthquake Engineering, Istanbul, Turkey, no. AT130, pp. 1-11, 2000.

[2] A. Doğangün, "Performance of reinforced concrete buildings during the May 1, 2003 Bingöl Earthquake in Turkey," Eng. Struct. vol. 26, no.6, pp. 841-856, 2004.

[3] R. Ulusay, Ö. Aydan, A. Erken, H. Kumsar, E.Tuncay, and Z.Kaya, "Site investigation and engineering evaluation of Çay-Eber Earthquake of February 3," Turkish Earthquake Foundation, Report No.: TDV/DR 012-79, pp. $213,2002$.

[4] A.Dogangun, H. Sezen, O. I. Tuluk, R. Livaoglu, and R. Acar, "Traditional Turkish Monumental Structures and their Earthquake Response," International Journal of Architectural Heritage, vol. 1, no. 3, pp. 251-271, 2007.

[5] B. Sevim, A. Bayraktar, A.C. Altunisik, S. Atamtürktür, and F.Birinci, "Assessment of nonlinear seismic performance of a restored historical arch bridge using ambient vibrations," Nonlinear Dynamics, vol. 63, no. 4, pp. 755-770, 2011.

[6] F. Ceroni, S. Sica, M.R. Pecce, and A. Garofano, "Evaluation of the natural vibration frequencies of a historical masonry building accounting for SSI," Soil Dynamics and Earthquake Engineering, vol. 64, pp. 95-101, 2014.

[7] H. Nohutcu, A. Demir, E. Ercan, E. Hokelekli, and G. Altintas, "Investigation of a historic masonry structure by numerical and operational modal analyses," The Structural Design of Tall and Special Buildings, vol. 24, no. 13, 2015. 
[8] C. Gentile, A. Saisi, A. Cabboi, "Structural identification of a masonry tower based on operational modal analysis," International Journal of Architectural Heritage, vol. 9, no. 2, pp. 98-110, 2015.

[9] A. Bayraktar, T. Turker and A.C. Altunisik, "Experimental frequencies and damping ratios for historical masonry arch bridges," Construction and Building Materials, vol. 75, pp. 234-241, 2015.

[10] A. Bayraktar, A. C. Altunisik, B. Sevim, T. Türker, M.Akköse, and N. Coşkun, "Modal analysis, experimental validation, and calibration of a historical masonry minaret," Journal of Testing and Evaluation, vol. 36, no. 6, pp. 516-524, 2008.

[11] A. Bayraktar, A. C. Altunisik, and B. Sevim, "Seismic response of a historical masonry minaret using a finite element model updated with operational modal testing," Journal of Vibration and Control, vol. 17, no. 1, pp. 129-149, 2011.

[12] ANSYS, Swanson Analysis System., Canonsburg, PA: Ansys, Inc., 2013.

[13] R. Brincker, L. Zhang, and P. Andersen, "Modal Identification from Ambient responses using Frequency Domain Decomposition," in Proceedings of the 18th International Modal Analysis Conference (IMAC), San Antonio, Texas, 2000.

[14] Ministry of Culture and Tourism, Yeşilırmak River Basin Development Union, Samsung Guide, 2010.

[15] SVS. (2013, May 1). ARTeMIS Modal Pro [Online]. Available: http://www.svibs.com

[16] R. Wei-Xin and C. Hua-Bing, "Finite element model updating in structural dynamics by using the response surface method,” Engineering Structures, vol. 32, pp. 2455-2465, 2010. 